\title{
European Version of A Balanced Scorecard in Family Enterprises (Own Research)
}

\author{
Adrianna Lewandowska \\ Warsaw School of Economics, \\ Family Business Institute, \\ Warsaw, Poland \\ E-mail:alewandowska@ibrpolska.pl
}

\begin{abstract}
The paper presents the European model of the Balanced Scorecard. It is based on the goals, which take into account the point of view of various stakeholders of the company. The main objective of the study was to demonstrate the differences in the two versions Balanced Scorecard: European and American. The specific objective of the research was the most common diagnosis liquidated barriers to family businesses, which are defined as critical to effective strategy implementation. The results of the study indicate significant differences in the application of both the Balanced Scorecard and include barriers: integration of the objectives of ownership, consistency and competence.
\end{abstract}

\section{Keywords: Balanced Scorecard; Family business}

\section{INTRODUCTION}

A developed strategy is only the beginning of the market game. A true challenge is the proper implementation of the defined goals. "Nine out of ten companies are unable to implement the strategy they developed" [1]. Increasing the effectiveness in closing the strategic gap becomes a new challenge for many managers. European model of Balanced Scorecard, based on goals and initiatives, which take into account the point of view of various stakeholders of the company becomes an interesting proposition for family enterprises, which aim to improve their strategic efficiency. The main objective of this paper was to present differences in two versions of BSC: European and American. The specific objective of the research was the diagnosis of most commonly liquidated barriers in family enterprises, which were defined as critical for effective implementation of strategy. The results of the study indicate significant differences in the application of both BSCs.

\section{THE NATURE AND CAUSES OF THE PROBLEMS IN THE EFFECTIVE IMPLEMENTATION OF THE STRATEGY}

Economic turbulences and increasingly aggressive competitive battle in world markets cause that more and more important role in the success and even the existence of the company is undeniably played by not only the mere possession of a well-developed strategy, but above all, the solid position of this strategy in the operating area which engages all employees. The Fortune magazine, in a report on the failures of CEOs of large companies, draws a conclusion that in $70 \%$ of cases the failure was caused by the inappropriate implementation of the strategy [2]. "Today's organizations need both the language in which they can convey information about strategy and processes and

\author{
Ewa Więcek-Janka \\ Poznan University of Technology \\ Faculty of Management Engineering \\ Poznan, Poland \\ E-mail: ewa.wiecek-janka@put.poznan.pl
}

systems which support the implementation of strategies and collecting feedback. Success comes when the strategy becomes common, everyday matter of all employees." [3] Everyday matter of employees is the operational activity closely linked with the strategic guidelines, and at the same time it is a big chance for successful implementation of the strategy.

Reaching for the literature of the subject, we can find a wide range of concepts developed in the last twenty years that help entrepreneurs in defining their business strategies. These methods facilitate decision-making with regard to the target segments, offered products, company's attitude toward competition [4], choice of technology [5], evaluate of the process manufacturing [6], purchasing decisions [7], etc. The essence of the strategy is, in fact, the choice of objectives, principles and rules that set direction of future actions, defining the size, combination and allocation of resources depending on changing market situation (environment, competition) [8]. Using a variety of portfolio techniques, clear guidelines are outlined for the company for the coming years based on the gathered information.

It might seem that having a well-developed vision of how the company intends to pursue its economic assumptions is enough to simply expect the results. Unfortunately, in reality it turns out that from the development of an effective strategy to achieving the expected results, contrary to appearances, there is much more to "be done" than at the beginning of the whole process of strategic management. Therefore, it becomes interesting to carry out a discussion on why, despite the properly formulated strategies, preceded by insightful market analysis, opportunities, threats, potential success etc., such vast majority of them remain a mere formality recorded in the company's brochures. There are a number of barriers hindering the effective implementation of the strategy and reflecting it in the everyday business: including the communication barrier - on the basis of analysis in American companies a thesis was set that in most organizations, about $70 \%$ of board members, $40 \%$ of middle managers and from $3-7 \%$ of the workforce understands the strategy [9], employees often do not see the connection between the work they do and defined strategic objectives [9]. A development of strategy, planning, problem solving - all these tasks need to be presented to the people at the lowest possible levels of the organization, working on the front line [10]. Barrier of resources, such as personnel, knowledge, very often are distributed with a short term perspective, for routine, operational activities. Long-term needs are often considered a distant future, which will have to be taken care of in second 
place. And it is these long-term needs which are critical factors of success. Lack of resources for their implementation causes frustration and ultimately resignation among employees. Barrier of correlation between budget and strategic planning - despite the fact that many companies use the budget as a basic management system in setting goals, allocating resources and assessing performance, half of them report that there is no clear link between strategic planning and budget [3]. A consequence of such approach is an incorrect allocation of resources and disorientation of employees. Barrier of consistence - often not only operational staff, directly involved in the implementation of strategic arrangements (assuming that in the company the long-term plans were translated into specific tasks), but also the members of highest management, who discouraged by the lack of immediate results, set other, sometimes contradicting goals, which improve results in short-term perspective but do not favor the realization of long-term assumptions. Divergence between strategic objectives and operational activities is often extremely large [11].

Appearing in the organization of these barriers which impede, or even make impossible to effectively implement the strategy and its realization through the daily operational activities is a signal that we should look for solutions preventing possible negative consequences of this state of affairs. Therefore, the use of the Balanced Scorecard, which enables merging of these two areas, seems to be highly relevant.

Helpful in reducing barriers associated with the implementation and execution of firm business strategy may also be functioning in a company certified quality management system, QMS in short. From the research described in results that an effective QMS is not only a way to ensure proper quality for the customer, but the QMS has also a positive impact on other factors of success of the company, including the increase in the level of employee satisfaction and their loyalty, clarity of information and communication in the company and even better outcomes and business performance [12], [13], [14].

\section{EUROPEAN VS AMERICAN VERSION OF THE BALANCED SCORECARD}

The concept of the Balanced Scorecard has a history of evolution, which is known around the world and is more and more commonly used in the strategic management ([15], [16], [17]). Currently the full potential of BSC is not limited only to an effective system of measurement, but is used primarily in the implementation of the strategy, translating generally outlined visions of the company to specifically defined measurable goals and building internal relationships to increase the level of involvement of all stakeholders ([18], [19], [20]).

In pursuing such stages of implementation sequence we must assume the interpretation of the Balanced Scorecard concept as a tool for facilitating the focusing of a group of people on achieving the same goals. The European version of the Balanced Scorecard developed in Germany by Friedag and Schmidt stronger than the American original underlines the importance of involving employees in the process of developing strategic initiatives [21]. As a result, the center of attention is not the financial increase of a company value, but the development of intellectual capital. It is the motivation and commitment of employees which are the core of a competitive advantage [21]. Resignation from the US strategic map, where the idea is to bring all the strategic actions to the financial dimension, underlines this approach. By taking into account the individual ambitions and aspirations of employees, strategic objectives are defined for the company, which are implemented with greater commitment, and consequently with better results. It is important to create a feeling in the company that goals of individual employees are respected, and all together they create the aspirations of the entire enterprise. Such setting of priorities by no means negates the previously existing standards related to the formulation of corporate strategy, and only complements them with "human" aspect, with consideration of the aspirations of the people, who together will be responsible for their implementation. The consequences of such an approach are favorable conditions for the creation of so-called emerging strategies. If employees have a sense of real influence on determining the direction of the company development, they will be more sensitive to signals from the changing environment and more likely to initiate the strategy updates.

Balanced Scorecard in European understanding postulates to consider during its construction the creation of interdepartmental task teams, which support each other and together seeking to attain its strategic objectives. The implementation of the BSC across the enterprise is done with the participation of employees at different levels of the organizational structure in the implementation of strategic projects, and not down the organizational structure of the company. Such implementation process improves the relations between departments, and consequently contributes to the increase of effectiveness of implementation. According to European experts, the most important element characterizing the learning process of the organization is: creating a basis for strategic dialogue [22]. It is important to create an atmosphere based on trust during the implementation of the strategy in organizations [23]. Then the employees have the courage to clearly and openly express their views, even if they do not comply with generally prevailing views, are willing to think creatively and search for the best solutions, even if certain decisions have already been made. Only such attitude of the staff allows for quick reactions in face of new circumstances affecting more or less directly the strategy. Only based on such behavior of employees we can create a learning organization, which is ready to change at any time when the need arises [24].

In this context it is important for the company effectively implementing the current strategy to be characterized also by the willingness to verify strategic assumptions. External impulses and experience acquired through strategic action, both individual and collective should become a part of the strategic management process. This will conclude the implementation circle, and at the same time will inaugurate the next round. This way, the Balanced Scorecard is 
implemented as an effective method of strategic management, uniting entire organization around the implementation of the strategy, as well as a way to keep certain flexibility necessary to respond to changes in the environment.

\section{METHODOLOGY OF RESEARCH ON ELIMINATING BARRIERS IN THE IMPLEMENTATION OF THE BSC}

To verify the application effectiveness of Balanced Scorecard a survey was conducted among family enterprises, which declared implementing or having implemented BSC.

The aim of the study is the diagnosis of barriers most often neutralized by the management and owners of family businesses that have been defined as critical to effective implementation of a strategy.

Research hypothesis set in the study: using the concept of Balanced Scorecard in the European version can neutralize most of the barriers hindering the implementation of the strategy.

- A qualitative study was conducted using focus group interviews. They were used to generate the data needed to answer three main groups of research questions.

- What are the key barriers hindering the effective implementation of strategies in family businesses?

- Which of them are neutralized or eliminated with a use of the BSC concept?

- Do owners of the companies that use the BSC concept modify and adjust it to their own needs?

The survey was conducted within 7 focus group interviews with the owners and employees of family businesses using the concept of Balanced Scorecard in company management. It was considered that the subject of study may require dialogue and in-team support, therefore the focus groups methods would be most suitable, because it allows to make use of the dynamics of a social group, and to diagnose positive impact of "5S" factors - synergy, snowballing, stimulation, security and spontaneity. A total of 54 people participating in the 5 thematic meetings were surveyed. In these teams there were representatives of companies that use the American and European version. The distribution of a sample: 32 to 22 .

After having been introduced to the topic, the participants were asked to interpret the barriers that effectively hindered the implementation of the assumed strategic plans before the Balanced Scorecard was applied. The groups of the barriers selected by the participants were classified and a total of 10 were selected, which they considered the most difficult to overcome. In second stage, the participants of the survey were asked to rank the ones that have been eliminated. Focus group interviews also helped to organize specific benefits. In the next phase of the study a questionnaire was constructed using a Likert scale, which is used, among others, in questionnaires to get an answer regarding the level of acceptance of a certain phenomenon, belief, etc. The authors used it to evaluate the results obtained in the first phase of the study (Table I).

TABLE I. IMPLEMENTATION OF THE STRATEGY WITH THE USE OF A BALANCED SCORECARD MODEL

\begin{tabular}{|c|c|c|c|}
\hline Barrier & \begin{tabular}{|c|} 
Comprehensive use \\
of a Balanced Scorecard concept
\end{tabular} & $\begin{array}{c}\text { American } \\
\text { version }\end{array}$ & $\begin{array}{l}\text { Europea } \\
\text { n version }\end{array}$ \\
\hline \begin{tabular}{c|} 
Barrier of \\
communication
\end{tabular} & $\begin{array}{l}\text { Flow of strategic information on all } \\
\text { levels of organization }\end{array}$ & 3.5 & 4.2 \\
\hline $\begin{array}{l}\text { Barrier of } \\
\text { resources }\end{array}$ & $\begin{array}{l}\text { Proper planning of resources } \\
\text { (taking into account both long and } \\
\text { short term needs) }\end{array}$ & 3.5 & 2.8 \\
\hline Barrier of time & $\begin{array}{l}\text { Focusing attention on strategic } \\
\text { issues }\end{array}$ & 1.9 & 1.6 \\
\hline $\begin{array}{l}\text { Barrier of } \\
\text { rewarding }\end{array}$ & $\begin{array}{l}\text { linking the tasks correlated with the } \\
\text { strategic objectives with the } \\
\text { motivation system }\end{array}$ & 2.7 & 2.4 \\
\hline $\begin{array}{c}\text { Barrier of } \\
\text { competencies }\end{array}$ & $\begin{array}{l}\text { Identification of key competencies } \\
\text { of employees, which are the } \\
\text { necessary condition for successful } \\
\text { implementation }\end{array}$ & 3.5 & 4.3 \\
\hline $\begin{array}{l}\text { Barrier of } \\
\text { connecting } \\
\text { strategy with } \\
\text { budget }\end{array}$ & $\begin{array}{l}\text { transposition of the thesis that the } \\
\text { budget serves the implementation } \\
\text { of the strategy, } \\
\text { and not the other way around. }\end{array}$ & 3.9 & 2.7 \\
\hline $\begin{array}{l}\text { Barrier of } \\
\text { consistency }\end{array}$ & $\begin{array}{l}\text { Implementation of systems } \\
\text { motivating to consistent fulfillment } \\
\text { of assumptions }\end{array}$ & 1.3 & 2.3 \\
\hline $\begin{array}{l}\text { Barrier of } \\
\text { formality }\end{array}$ & $\begin{array}{l}\text { Formalizing necessary aspects in an } \\
\text { accessible and transparent manner }\end{array}$ & 3.9 & 2.7 \\
\hline $\begin{array}{c}\text { Barrier of } \\
\text { updates }\end{array}$ & Current updating of strategic plans & 2.5 & 4.5 \\
\hline $\begin{array}{l}\text { Barrier of } \\
\text { integration of } \\
\text { owners' goals }\end{array}$ & $\begin{array}{l}\text { Connecting the strategic goals of } \\
\text { the company with the goals of } \\
\text { owners by introducing additional } \\
\text { perspective. }\end{array}$ & 2.5 & 4.0 \\
\hline
\end{tabular}

Source: work by own

The study showed differences between the scope and degree of use of BSC for eliminating the strategic barriers (Fig. 1). Companies in which the BSC was implemented in the classical approach have a higher level of formalization (barrier was eliminated in a smaller degree), and the owners' goals have not been integrated. This result was in a way surprising, as one could expect the natural integration of the owners' objectives with the financial perspective. The European version of the BSC on the other hand strongly emphasizes the development of employees' competencies and largely eliminates the barrier of communication. None of the versions however gives full satisfaction to users in the area of the elimination of the barriers of time for the implementation of the strategy and focus on strategic issues. In focus group surveys participants suggested that the area of strategy somehow "was added" to the previous areas of competencies and became an additional area of tasks and responsibilities. 


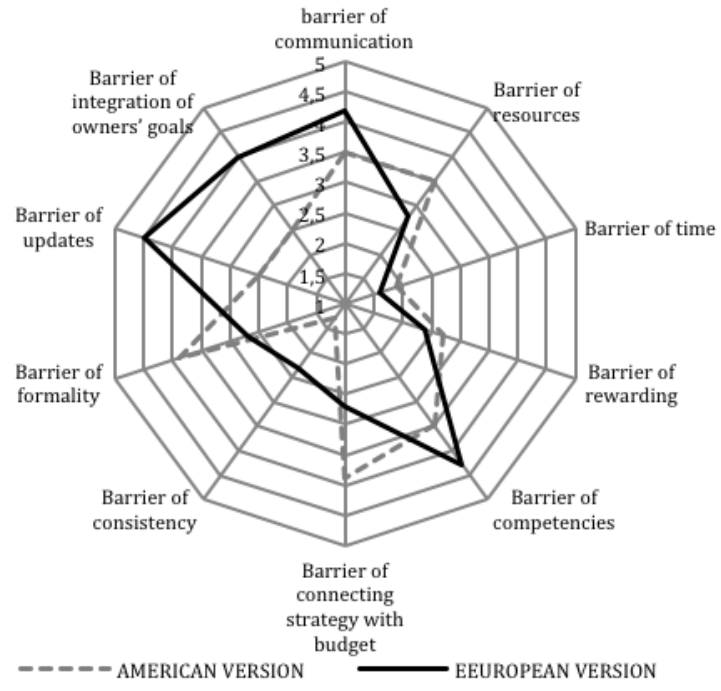

Figure 1. Eliminating barriers to implementation of strategy through the use of the concept of Balanced Scorecard.

\section{EUROPEAN MODEL OF BSC WITH ADAPTATION VERSION}

Applying the concept of Balanced Scorecard in such scope, the organization opens up to an opportunity to focus the company on a continuous implementation of the strategy. According to Penc [25] such an approach, called "strateging" contributes not only to the implementation of strategic objectives and maintaining their flexibility, but mainly leads to the improvement of the organization. "Strateging - This is undoubtedly the method of the future, requiring the preparation of specialists who are able to use modern information technology and understand that strategy is the most important and critical factor of success, but it requires fulfilling several conditions, including: adequate resources and implementation potential, systems and structures as management tools, philosophy and corporate culture as catalysts for the introduction of the strategy. Only the use of entire range of enterprise's functions to support strategy is the key to its future success" [25].

Using the European version of the concept of Balanced Scorecard, an organization has a chance to prevent the creation of barriers to effective implementation of the strategy. If the organization measures key factors from the strategy perspective, it should be assumed that the results of these studies and their interpretation, analysis of trends, etc. are openly presented to all employees. This situation contributes to global distribution of the degree of implementation of the strategy, to employees' identification with the objectives, which reach their optimal values faster than planned. So called weaker spots, which delays achieving the desired results are quicker and more effectively identified. Such information is valuable not only because of the possibility to perform an ongoing analysis of the company in the context of its strategic objectives, but also, in the event of significant deviations from the planned individual measures, allows for their quick identification.
Balanced Scorecard also enhances the correlation between strategy and the budget, both long- and short-term, however implying the strategic arrangements. Operating activities being under the strict influence of the strategic assumptions are reflected in certain results, which give feedback to the Board. On the basis of this information assessment and analysis of strategic achievements of the company and their verification with regard to their current state is performed. The loop of strategic learning at the same time closes and starts again. In summary, it can be concluded that by properly guiding the process of the implementation of the BSC, we can achieve effective elimination of barriers to the effective implementation of the strategy, and thus increase the efficiency of the company.

\section{REFERENCES}

[1] G. K. Świderska, Management information in the formulation and implementation of strategy, [Informacja zarządcza w procesie formułowania i realizacji strategii], Difin, Warsaw, 2003.

[2] W. Jankowski, From strategy to scorecard [Od strategii do karty wyników], QMS - Press "Global Business", vol. 6, 2001.

[3] R. Kaplan, D. Norton, "The Balanced Scorecard-Measures That Drive Performance," Harvard Business Review, pp. 71-79, JanuaryFebruary 1992.

[4] E. Więcek-Janka, R. Mierzwiak, J. Kijewska, "Competencies' Model in the Succession Process of Family Firms with the Use of Grey Clustering Analysis," The Journal of Grey System, vol. 28, no 2, pp. 121-131, 2016.

[5] W. Wrzosek (ed.), Marketing strategies [Strategie marketingowe], Publishing House of Warsaw School of Economics, Warsaw, 2001.

[6] A. Kujawińska, M. Rogalewicz, M. Diering, M. Piłacińska, A. Hamrol, A. Kochański, "Assessment of ductile iron casting process with the use of the DRSA method," Journal of Mining and Metallurgy, Section B: Metallurgy, vol. 52, no 1, pp. 25-34, doi:10.2298/ JMMB150806023K, 2016.

[7] A. Kujawińska, M. Rogalewicz, M. Diering, "Application of expectation maximization metod for purchase decision-making support in welding branch," Management and Production Engineering Review, vol. 7, no 2, pp. 29-33, June 2016. doi: 10.1515/mper-20160014.

[8] Ph. Kotler, "Marketing. Marketing. Analysis, planning, implementation and control," The Prentice-Hall Series in Marketing, Prentice Hall; 8th edition, 1994.

[9] G. Leonhardt, Balanced Scorecard in practice [Strategiczna Karta Wyników w praktyce], Publishing Agency IMG AG Warsaw, 2001.

[10] T. Lambert, Problems of management [Problemy zarządzania], Publishing House ABC, Warsaw, 1999.

[11] K. Obłój, The material of effective strategies [Tworzywo skutecznych strategii], State Publishing House of Economic, Warsaw, 2002.

[12] S.Jasarevic, M. Diering, S. Brdarevic, Opinions of the consultants and cartification houses regarding the quality factors and achived effects of the introduced quality system, Technicki Vjesnik-Technical Gazette, Volume: 19, Issue: 2, pp 211-220, 2012, UDC/UDK 658.562.011:061.238.

[13] P. Drożyner, P. Mikołajczak, J.Szuszkiewicz, M. JasiulewiczKaczmarek, "Management standardization versus quality of working life," in: M.M. Robertson (ed.), Ergonomics and Health Aspects, HCII 2011, LNCS 6779, () Springer-Verlag Berlin Heidelberg, 2011, pp. 30-39, DOI: 10.1007/978-3-642-21716-6.

[14] A. Mazur, A. Stachowiak, "The framework of methodology for identification of organizational maturity with assessment of exelence level of logistic system," in: Abrudan I. (ed), The Management Between Profit and Social Responsibility, [Proceedings of the 4th Review of Management ond Economic Engineering International 
Management Conference, 18-20 September 2014], Todesco Publishing House, Cluj-Napoca, Romania, 2014, pp. 415-423.

[15] E. Urbanowska-Sojkin, P. Banaszyk, H. Witczak, Strategic management of enterprise [Zarządzanie strategiczne przedsiębiorstwem], State Publishing House of Economic, Warsaw, 2004.

[16] F. De Geuser, S. Mooraj and D. Oyon, "Does the balanced scorecard add value? Empirical evidence on its effect on performance." European Accounting Review. vol. 18, no.1, pp. 93-112, 2009. DOI: $10.1080 / 09638180802481698$.

[17] P.R. Niven, "What Exactly is a Balanced Scorecard?, in Balanced Scorecard Evolution: A Dynamic Approach to Strategy Execution," John Wiley \& Sons, Inc., Hoboken, NJ, USA, 2014, DOI: 10.1002/9781118915011.ch1.

[18] B. Bigliardi, E. Bottani, "Implementing the balanced scorecard in the mechanical industry: Evidence from a case study," International Journal of Management and Decision Making, vol. 11, no.2, pp. 140162, 2010. DOI 10.1504/ijmdm.2010.035214.

[19] W.G. Bremser, N.P. Barsky, "Utilizing the balanced scorecard for R\&D performance measurement," R\&D Management vol. 34, no.3, pp. 229-238, 2004. DOI: 10.1111/j.1467-9310.2004.00335.x.
[20] M. Jasiulewicz-Kaczmarek, Socio-technical integrity in maintenance activities, in: Vink P. (ed.), Advances in Social and Organizational Factors, CRC Press, 2012, pp. 582-592, Print ISBN: 978-1-43987019-8.

[21] H. Friedag, W. Schmidt, A. Lewandowska, M. Likierski, My Balanced Scorecard [Moja Strategiczna Karta Wyników], C.H. Beck, Warsaw, 2003.

[22] J. Szambelan, Soft management. Contemporary problems of managing people [Miękkie zarządzanie. Ze współczesnych problemów zarządzania ludźmi], Publishing House of School of Business and Management L.Koźmiński, Warszawa, 2003.

[23] U. Krystek, S. Zumbrock, Planung und Vertrauen, Poeschell, Stuttgart, 1993.

[24] D. Ulrich, Leaders of human resources management [Liderzy zarządzania zasobami ludzkimi], ABC Publishing House, Krakow, 2001.

[25] J. Penc, Management strategies [Strategie zarządzania], Publishing Agency: Placet, Warsaw, 1995. 